\title{
Risk-benefit of dexrazoxane for preventing anthracycline-related cardiotoxicity: re-evaluating the European labeling
}

\author{
Peter Reichardt*,1, Marie-Dominique Tabone ${ }^{2}$, Jaume Mora ${ }^{3}$, Bruce Morland ${ }^{4}$ \& Robin L \\ Jones 5 \\ ${ }^{1}$ Department of Oncology, Helios Klinikum Berlin-Buch, Berlin, Germany \\ ${ }^{2}$ Department of Paediatric Onco-Haematology, Trousseau Hospital, Paris, France \\ ${ }^{3}$ Department of Pediatric Hematology \& Oncology, Hospital Sant Joan de Déu, Barcelona, Spain \\ ${ }^{4}$ Oncology Department, Birmingham Children's Hospital NHS Foundation Trust, Birmingham, UK \\ ${ }^{5}$ Division of Clinical Studies, Institute of Cancer Research \& Sarcoma Unit of the Royal Marsden NHS Foundation Trust, London, UK \\ *Author for correspondence: Tel.: +49 3094015 4800; Fax: +49 3094015 4809; peter.reichardt@helios-gesundheit.de
}

Dexrazoxane can prevent anthracycline-associated cardiotoxicity. However, in 2011, its use in children was contraindicated by the EMA over concerns of increased risk of infection, myelosuppression and second primary malignancies, and because its efficacy in children had not then been established. We review here the evidence published since 2011, which confirms that dexrazoxane is an effective cardioprotectant in children and adolescents, is not associated with an increased risk of second primary malignancies or excess early or late mortality and does not impair chemotherapy efficacy. Based on this evidence, the contraindication for children and adolescents requiring high doses of anthracyclines and at risk for cardiotoxicity was removed from the European labeling for dexrazoxane.

First draft submitted: 15 March 2018; Accepted for publication: 27 April 2018; Published online: 11 May 2018

Keywords: anthracycline $\bullet$ cardioprotective agents $\bullet$ clinical efficacy $\bullet$ dexrazoxane $\bullet$ doxorubicin $\bullet$ epirubicin - safety • second malignancy • survival

Dexrazoxane has been used in cancer patients to prevent anthracycline-related cardiotoxicity since the 1980s. In 2010, the Medicines and Healthcare Products Regulatory Agency in the UK requested that the Committee for Medicinal Products for Human Use (CHMP) review the use of dexrazoxane as a cardioprotectant. The Medicines and Healthcare Products Regulatory Agency specifically asked the EMA to analyze the cardioprotective efficacy of dexrazoxane and its association with increased risks of infection, myelosuppression and second primary malignancies (SPMs). In September 2011, the CHMP published the outcome of a referral [1] that recommended several restrictions on dexrazoxane use in both children and adults with cancer.

The CHMP argued that, in children and adolescents, the efficacy of dexrazoxane had not been established; dexrazoxane increased the risk of SPMs (particularly acute myeloid leukemia-myelodysplastic syndrome [AML/MDS]) in children with Hodgkin lymphoma; and dexrazoxane was associated with an increased risk of other toxicities, including neutropenia, sepsis and thrombocytopenia [1]. The CHMP concluded that "the safety and efficacy of dexrazoxane in children have not been established and that dexrazoxane should therefore not be used in children due to the risk of SPMs and potentially negative pharmacodynamic interactions with anthracyclines". Based on these findings, the CHMP recommended that dexrazoxane be contraindicated in children and adolescents.

For adults, the CHMP determined that dexrazoxane did prevent anthracycline-associated cardiotoxicity [1]. However, the CHMP also stated that dexrazoxane was associated with an increased risk of myelosuppression and excess early mortality. Given these findings, the CHMP recommended that the ratio of dexrazoxane to doxorubicin be reduced from 20:1 to 10:1. The CHMP also had concerns about dexrazoxane affecting the efficacy of anthracycline treatment and that acute myeloid leukemia (AML) had been identified as an uncommon adverse reaction. After this referral, the therapeutic indication for dexrazoxane was restricted in Europe to preventing 
chronic cumulative anthracycline-related cardiotoxicity in adults with advanced and/or metastatic breast cancer who had received a prior cumulative dose of $300 \mathrm{mg} / \mathrm{m}^{2}$ of doxorubicin or $540 \mathrm{mg} / \mathrm{m}^{2}$ of epirubicin [2].

In 2015, the European marketing authorization holder for Cardioxane ${ }^{\circledR}$ (dexrazoxane; Clinigen Healthcare Ltd, Staffordshire, UK) submitted an application to all relevant national regulatory authorities, including the French Health Products Safety Agency (Agence nationale de sécurité du médicament et des produits de santé; ANSM). The application reviewed the benefit-risk profile of dexrazoxane for both adults and children and proposed widening the indication from 'advanced and/or metastatic adult breast cancer patients' to 'cancer patients' and removing the contraindication in children and adolescents. The proposal to widen the indication was declined. However, discussion concerning the contraindication in children was ultimately referred to the CHMP for arbitration, and the Committee agreed that the contraindication should be lifted for children and adolescents requiring high doses of anthracyclines who are at risk of harmful cardiac effects. The CHMP limited the contraindication for dexrazoxane to children aged 0-18 years who are expected to receive a cumulative dose of less than $300 \mathrm{mg} / \mathrm{m}^{2}$ of doxorubicin or the equivalent cumulative dose of another anthracycline [3]. The European Commission issued an EU-wide decision to implement the CHMP recommendations on 19 July 2017 [4]. This change in the contraindication, along with other changes to the safety information reflecting current clinical and scientific knowledge relating to early death, SPMs and interference with chemotherapy, was approved in the Cardioxane label on 22 August 2017.

Here, we review the evidence supporting the benefit-risk profile of dexrazoxane in children and adults with cancer receiving anthracycline therapy that led to reassessment of the label for Cardioxane. We focus primarily on studies in patients consistent with the revised label that have been published since the original 2011 EMA appraisal, including papers published since the 2015 application to the regulatory authorities in the EU.

\section{Materials \& methods \\ Literature search}

We searched PubMed for articles on dexrazoxane published between 1 January 2011 and 20 August 2017. All publications that reported the use of dexrazoxane were collected, regardless of the findings and study design. Publications consistent with the revised label for Cardioxane were included in the analysis; that is, studies of dexrazoxane used to prevent chronic, cumulative anthracycline-related cardiotoxicity in adults with advanced and/or metastatic breast cancer who had received a prior cumulative doxorubicin dose of $300 \mathrm{mg} / \mathrm{m}^{2}$ or a prior cumulative epirubicin dose of $540 \mathrm{mg} / \mathrm{m}^{2}$ when further anthracycline treatment was required and in children from birth to 18 years old who were to receive a cumulative dose of more than $300 \mathrm{mg} / \mathrm{m}^{2}$ of doxorubicin or the equivalent cumulative dose of another anthracycline. Meta-analyses were included in this review if most patients included in the analyses had an indication for dexrazoxane treatment consistent with the revised label.

\section{Research questions}

We address several concerns raised by the CHMP in response to the Assessment Report for the Article 31 referral of Directive 2001/83/EC [1], namely that:

- The data for dexrazoxane use in children are insufficient and the efficacy of dexrazoxane has not been established;

- Dexrazoxane might be associated with an increased risk of SPMs;

- Dexrazoxane might be associated with specific toxicities, including myelosuppression, that might delay anticancer treatment;

- Dexrazoxane might be associated with excess early mortality;

- Dexrazoxane might impair the antitumor efficacy of anthracyclines.

\section{Results}

We identified 159 relevant publications and abstracts. Of these, 24 were clinical studies investigating the efficacy or safety of dexrazoxane, four were case studies or case series, one was a clinical article on the use of dexrazoxane [5] and seven studies were meta-analyses or systematic reviews. The remaining 123 publications were excluded as they did not report primary clinical data. These were general reviews $(\mathrm{n}=38)$, animal studies $(\mathrm{n}=34)$, in vitro studies $(\mathrm{n}=21)$, nonclinical studies focused on the use of dexrazoxane to prevent anthracycline extravasation $(\mathrm{n}=14)$, editorials $(n=5)$, articles that mentioned dexrazoxane in passing $(n=5)$ and technical studies $(n=6)$.

When we limited the results to publications consistent with the revised label for Cardioxane, 13 clinical trials [6-18] and four meta-analyses or systematic reviews remained [19-22]. These meta-analyses and systematic 
reviews predominantly summarized data from older (pre-2011) studies. However, one meta-analysis by Shaikh and colleagues [21] included studies of children that are mentioned individually below.

\section{Dexrazoxane is an effective cardioprotectant in children}

Since the CHMP review, 11 relevant publications have examined the use of dexrazoxane in children [6,7,9-12,14-18]. The Children's Oncology Group (COG) P9404 randomized trial evaluated oncologic efficacy, cardioprotective effectiveness and safety following dexrazoxane therapy in 537 children and adolescents with newly diagnosed T-cell acute lymphoblastic leukemia (ALL) or lymphoblastic non-Hodgkin lymphoma (Table 1) [6]. Every investigated echocardiographic measure was significantly better at 3 years in patients receiving dexrazoxane, including left ventricular (LV) fractional shortening z-score $(p=0.005)$, LV wall thickness $z$-score $(p=0.01)$ and LV thicknessto-dimension $\mathrm{z}$-score $(\mathrm{p}=0.006$ ) (Table 1$)$. This cardioprotection was achieved without compromising the efficacy of chemotherapy and did not lead to an increase in SPMs (discussed below).

In a retrospective analysis of 258 children with cancer treated with any anthracycline, the dose-limiting cardiotoxicity rate was significantly higher in the group that did not receive dexrazoxane $(p=0.006)$ [9]. In children with cumulative anthracycline doses of 200 or $300 \mathrm{mg} / \mathrm{m}^{2}$, LV ejection fraction and shortening fraction z-scores were significantly higher in those who received dexrazoxane than in those who did not ( $\mathrm{p}<0.04$ for all). Neither LV ejection fraction nor shortening fraction z-scores differed between groups at anthracycline doses of $400 \mathrm{mg} / \mathrm{m}^{2}$ or greater. Of the patients included in this study, 73 of 258 (28.3\%) had tumor types that fell outside the revised EU label (neuroblastoma, hepatoblastoma or other tumors).

Part of the Pediatric Oncology Group/Children's Cancer Group Pilot Intergroup protocol COG P9754 investigated dexrazoxane in 242 patients with osteosarcoma treated with a cumulative doxorubicin dose of $600 \mathrm{mg} / \mathrm{m}^{2}$ (Table 1) [14]. A third of the patients were over the age of 15 years (up to 30 years old). Dexrazoxane was associated with minimal reductions in LV fractional shortening z-scores and only primarily transient, low-grade LV dysfunction. In addition, a biomarker study in 205 patients with ALL (Dana-Farber Cancer Institute [DFCI] Protocol 95-01) found that mean cardiac troponin $(\mathrm{p}=0.005)$ and $\mathrm{N}$-terminal probrain natriuretic peptide concentrations $(\mathrm{p}=0.07)$ were lower in children who received dexrazoxane than those who did not [11]. Collectively, these results indicate that dexrazoxane is cardioprotective in children and adolescents who received anthracycline-based chemotherapy.

A 2016 meta-analysis by Shaikh and colleagues (17 studies; 4639 patients) of children receiving anthracycline chemotherapy concluded that dexrazoxane was associated with reduced subclinical (defined as asymptomatic changes in echocardiographic measures beyond specified thresholds) and clinical cardiotoxicity in randomized controlled trials (relative risk [RR]: 0.29, 95\% CI: 0.13-0.64) and with reduced subclinical cardiotoxicity, clinical cardiotoxicity or both in nonrandomized studies [21]. Other meta-analyses of similar populations also confirm the cardioprotective effect of dexrazoxane $[19,20]$.

\section{Dexrazoxane does not increase the risk of SPMs}

The CHMP conclusion in 2011 regarding the higher incidence of SPMs with dexrazoxane was predominately based on the results of one analysis by Tebbi and colleagues in children with Hodgkin lymphoma (COG studies P9425 and P9426) [24-26]. In this study, ten cases of SPM were reported; eight in the dexrazoxane group ( $\mathrm{n}=239$; six cases of AML/MDS and two of solid tumors) and two cases in the control group ( $\mathrm{n}=239$; both of AML/MDS) [24]. Long-term follow-up of 255 patients from COG P9426 found eight patients with SPMs (six previously reported), five were first events (three AML, one thyroid carcinoma and one osteosarcoma), and three cases occurred after relapse [27]. Of the five first events, four were in patients receiving dexrazoxane. The authors concluded that the difference in the number of SPMs between the two groups might be attributed to three topoisomerase II inhibitors (doxorubicin, etoposide and dexrazoxane) rather than to the effect of any single agent. In support of this finding, a retrospective study found that etoposide, but not dexrazoxane, was associated with secondary AML (odds ratio [OR]: 2.36, 95\% CI: 1.48-3.79) [15]. Other studies have also noted relatively high rates of secondary AML with etoposide (DFCI 05-01) [17].

The cumulative dose of doxorubicin $\left(100 \mathrm{mg} / \mathrm{m}^{2}\right.$ for early responders [two cycles] and $200 \mathrm{mg} / \mathrm{m}^{2}$ for nonearly responders [four cycles]) used by Tebbi and colleagues is below the cut-off in the 2017 revision of the dexrazoxane labeling [3]; dexrazoxane remains contraindicated in children receiving a cumulative dose under $300 \mathrm{mg} / \mathrm{m}^{2}$.

None of the studies identified in this review reported a significantly increased risk of SPMs after dexrazoxane treatment in children (Table 2) $[6,7,14,15,17,18]$. A retrospective study of 15,532 cancer patients identified secondary 
Table 1. Studies of the cardioprotective effects of dexrazoxane in children and adolescents with hematological or solid tumors receiving anthracycline-based chemotherapy published after 1 January 2011.

\begin{tabular}{|c|c|c|c|c|}
\hline $\begin{array}{l}\text { Study design and } \\
\text { reference }\end{array}$ & Patients & $\begin{array}{l}\text { Anthracycline (DOX) and } \\
\text { dexrazoxane (DRZ) doses and } \\
\text { sample sizes }\end{array}$ & Results and comments & Ref. \\
\hline $\begin{array}{l}\text { Randomized } \\
\text { COG P9404 }\end{array}$ & $\begin{array}{l}\mathrm{T}-\mathrm{ALL} \text { or } \mathrm{LB}-\mathrm{NHL} \\
\leq 22 \text { years old }\end{array}$ & $\begin{array}{l}\text { Treatment details published } \\
\text { in [23] } \\
\text { DOX: } 30 \mathrm{mg} / \mathrm{m}^{2} / \text { infusion with } \\
(\mathrm{n}=273) \text { or without }(\mathrm{n}=264) \\
\text { DRZ }(10: 1)^{\dagger} \\
\text { Cumulative DOX dose: } \\
360 \mathrm{mg} / \mathrm{m}^{2}\end{array}$ & $\begin{array}{l}\text { Mean LV FS, WT and TD } z \text {-scores were significantly better in } \\
\text { the DRZ group after } 3 \text { years: } \\
\text { LV FS results at } 3 \text { years: }-0.77 \text { (no DRZ), }-0.05 \text { (DRZ; } p=0.005) \\
\text { LV WT results at } 3 \text { years: }-0.69 \text { (no DRZ), }-0.13(D R Z ; p=0.01) \\
\text { LV TD results at } 3 \text { years: }-0.75 \text { (no DRZ), }-0.09 \text { (DRZ; } p=0.006)\end{array}$ & [6] \\
\hline Retrospective & $\begin{array}{l}\text { Children with cancer } \\
<18 \text { years old }(73 / 258[28.3 \%] \\
\text { patients outside the indicated } \\
\text { population) }\end{array}$ & $\begin{array}{l}\text { Anthracycline alone }(\mathrm{n}=123) \text { or } \\
\text { combined with DRZ } \\
\text { (concomitantly with low } \\
\text { anthracycline dose: }<100 \mathrm{mg} / \mathrm{m}^{2} \text {, } \\
\mathrm{n}=85 \text {; or after a higher dose: } \\
>100 \mathrm{mg} / \mathrm{m}^{2}, \mathrm{n}=50 \text { ) } \\
\text { Cumulative anthracycline dose: } \\
\text { up to } 500 \mathrm{mg} / \mathrm{m}^{2}\end{array}$ & $\begin{array}{l}\text { During chemotherapy, dose-limiting cardiotoxicity rate was } \\
\text { significantly higher }(p=0.006) \text { in the anthracycline-only } \\
\text { group }(7.3 \%) \text { vs the high- }(2.0 \%) \text { and low-dose }(0 \%) \\
\text { anthracycline groups treated with DRZ. In addition, LVEF } \\
\text { and shortening fraction z-scores were greater in the } \\
\text { concomitant low-dose anthracycline + DRZ group than in } \\
\text { the anthracycline-only group } \\
\text { LVEF and shortening fraction z-scores did not differ } \\
\text { significantly between groups when patients received a } \\
\text { cumulative anthracycline dose }>400 \mathrm{mg} / \mathrm{m}^{2} \\
\text { Early use of DRZ protects against cardiotoxicity during } \\
\text { anthracycline therapy in children }\end{array}$ & [9] \\
\hline $\begin{array}{l}\text { Noncomparative } \\
\text { COG P9754 }\end{array}$ & $\begin{array}{l}\text { Osteosarcoma }<31 \text { years old } \\
\text { (median age } 13-14 \text { years) }\end{array}$ & $\begin{array}{l}\text { DOX: } 37.5 \mathrm{mg} / \mathrm{m}^{2} / \text { infusion plus } \\
\text { DRZ: } 375 \mathrm{mg} / \mathrm{m}^{2}(10: 1)^{\dagger}(\mathrm{n}=242) \\
\text { Cumulative DOX dose: } \\
600 \mathrm{mg} / \mathrm{m}^{2}\end{array}$ & $\begin{array}{l}\text { Mean (SD) LV FS z-score showed minimal reductions ( } 0.017 \\
\text { [0.009]/week) over } 78 \text { weeks } \\
\text { Grade } 1 / 2 \text { LV dysfunction occurred in five patients (four had } \\
\text { transient effects) } \\
\text { Minimal reductions in LV FS z-scores and only primarily } \\
\text { transient, low-grade LV dysfunction was observed following } \\
\text { DRZ treatment }\end{array}$ & [14] \\
\hline $\begin{array}{l}\text { Randomized } \\
\text { COG P9404, COG } \\
\text { P9425, COG P9426; } \\
\text { pooled analysis }\end{array}$ & $\begin{array}{l}\text { T-ALL/lymphoma }(n=537) \\
\text { intermediate-high-risk HL } \\
(n=216) \text {, low-risk HL }(n=255) \\
\leq 22 \text { years old }\end{array}$ & $\begin{array}{l}\text { DOX: } 25-30 \mathrm{mg} / \mathrm{m}^{2} / \text { infusion } \\
\text { with }(\mathrm{n}=507) \text { or without } \\
(\mathrm{n}=501) ; \mathrm{DRZ}(10: 1)^{\dagger} \\
\text { Cumulative DOX dose: } \\
100-360 \mathrm{mg} / \mathrm{m}^{2}\end{array}$ & $\begin{array}{l}\text { No patient died from a cardiovascular cause, although it } \\
\text { was listed as a secondary cause for four patients. These } \\
\text { patients included one with an acute myocardial infarct and } \\
\text { one with a stroke (both received DRZ), and two with } \\
\text { cardiomyopathy/heart failure (neither received DRZ). The } \\
\text { underlying cause of death in these four patients was the } \\
\text { original tumor } \\
\text { DRZ is not associated with deaths from cardiovascular causes }\end{array}$ & [7] \\
\hline $\begin{array}{l}\text { Partially } \\
\text { randomized } \S \\
\text { DFCI 87-01, DFCI } \\
91-01, \text { DFCI 95-01, } \\
\text { DFCI 00-01; pooled } \\
\text { analysis }\end{array}$ & $A L L \leq 30$ years old & $\begin{array}{l}\text { DOX: } 30 \mathrm{mg} / \mathrm{m}^{2} / \text { infusion } \\
\text { DRZ: } 300 \mathrm{mg} / \mathrm{m}^{2} \\
\text { Cumulative DOX dose: } \\
300 \mathrm{mg} / \mathrm{m}^{2}(95-01 \text { and } 00-01) \text { or } \\
375 \mathrm{mg} / \mathrm{m}^{2}(87-01 \text { and } 91-01) . \text { In } \\
\text { total, } 70 \text { high-risk patients } \\
\text { received DRZ and } 61 \text { high-risk } \\
\text { patients did not }\end{array}$ & $\begin{array}{l}\text { A NOS3 genotype-related difference in EF was seen in } \\
\text { high-risk patients who did not receive DRZ (mean } \\
\text { difference: } 64.1 \text { vs } 56.8 \% ; p=0.002) \text {, but not in patients } \\
\text { who received DRZ ( } 64.4 \text { vs } 64.5 \% ; p=0.99 \text { ) } \\
\text { DRZ can counter the negative effect of specific NOS3 } \\
\text { polymorphisms on cardiac function }\end{array}$ & [10] \\
\hline $\begin{array}{l}\text { Randomized } \\
\text { DFCI 95-01 }\end{array}$ & ALL (high-risk) $<18$ years old & $\begin{array}{l}\text { DOX: } 30 \mathrm{mg} / \mathrm{m}^{2} / \text { infusion with } \\
(\mathrm{n}=105) \text { or without }(\mathrm{n}=100) \\
\text { DRZ }(10: 1)^{\dagger} \\
\text { Cumulative DOX dose: } \\
300 \mathrm{mg} / \mathrm{m}^{2}\end{array}$ & $\begin{array}{l}\text { cTnT levels: DOX: } \uparrow 47 \% \text { vs DOX plus DRZ: } \uparrow 13 \%(p=0.005) \\
\text { NT-proBNP levels: DOX: } \uparrow 48 \% \text { vs DOX plus DRZ: } \uparrow 20 \% \\
\text { ( } p=0.07 \text { ) } \\
\text { The increases in cTnT were associated with abnormally } \\
\text { reduced LV mass and end-diastolic posterior wall thickness } \\
\text { after } 4 \text { years ( } p<0.01) \text {. Increases in NT-proBNP were related } \\
\text { to abnormal LV thickness-to-dimension ratio after } 4 \text { years } \\
(p=0.01)\end{array}$ & [11] \\
\hline Retrospective & $\mathrm{AML}<21$ years old & $\begin{array}{l}\text { Anthracycline }(n=16) \text { alone or } \\
\text { combined with DRZ }(n=28)\end{array}$ & $\begin{array}{l}E F(p=0.03) \text { and shortening fraction } z \text {-scores }(p=0.04) \text { were } \\
\text { significantly higher in DRZ patients than patients treated } \\
\text { with chemotherapy alone }\end{array}$ & [13] \\
\hline \multicolumn{5}{|c|}{$\begin{array}{l}\text { †Dose ratio DRZ:anthracycline. } \\
\text { ¥Results from the P9754 trial were also included in the abstract. The results from this trial were published subsequently in reference [14]. } \\
\text { §In study 95-01 patients were randomly assigned to receive or not receive DRZ and in study 00-01 all high-risk patients received DRZ. } \\
\text { ALL: Acute lymphoblastic leukemia; AML: Acute myelogenous leukemia; Crl: Bayesian credible interval; DFCI: Dana-Farber Cancer Institute; DOX: Doxorubicin; DRZ: Dexrazoxane; } \\
\text { EF: Ejection fraction; FS z-score: Fractional shortening z-score; HF: Heart failure; HL: Hodgkin lymphoma; LB-NHL: Lymphoblastic non-Hodgkin lymphoma; LV: Left ventricular; LVEF: } \\
\text { Left ventricular ejection fraction; OR: Odds ratio; RCT: Randomized controlled trial; RR: Relative risk; SD: Standard deviation; TD z-score: Thickness-to-dimension z-score; T-ALL: T-cell } \\
\text { acute lymphoblastic leukemia; WT z-score: Wall thickness z-score. }\end{array}$} \\
\hline
\end{tabular}


Table 1. Studies of the cardioprotective effects of dexrazoxane in children and adolescents with hematological or solid tumors receiving anthracycline-based chemotherapy published after 1 January 2011 (cont.).

\begin{tabular}{|c|c|c|c|c|}
\hline $\begin{array}{l}\text { Study design and } \\
\text { reference }\end{array}$ & Patients & $\begin{array}{l}\text { Anthracycline (DOX) and } \\
\text { dexrazoxane (DRZ) doses and } \\
\text { sample sizes }\end{array}$ & Results and comments & Ref. \\
\hline $\begin{array}{l}\text { Meta-analysis ( } 17 \\
\text { studies; } \\
4639 \text { patients) }\end{array}$ & $\begin{array}{l}\text { Children with cancer treated } \\
\text { with DRZ as a cardioprotectant } \\
\text { Most patients in each included } \\
\text { study had to be }<18 \text { years old }\end{array}$ & $\begin{array}{l}\text { Anthracycline alone or combined } \\
\text { with DRZ (10:1 to } 20: 1)^{\dagger} \\
\text { Mean/median cumulative } \\
\text { anthracycline dose in some of the } \\
\text { included studies was an } \\
\text { equivalent doxorubicin dose of } \\
<300 \mathrm{mg} / \mathrm{m}^{2}\end{array}$ & $\begin{array}{l}\text { DRZ did not affect clinical cardiotoxicity in RCTs because of a } \\
\text { low event rate ( } 3 \text { events among all patients). DRZ was } \\
\text { associated with a reduction in subclinical or clinical } \\
\text { cardiotoxicity in RCTs (RR: } 0.29,95 \% \mathrm{Cl}: 0.13-0.64) \text { and } \\
\text { reductions in both clinical cardiotoxicity (RR: } 0.29,95 \% \mathrm{Cl} \text { : } \\
0.14-0.61 \text { ) and subclinical or clinical cardiotoxicity in } \\
\text { nonrandomized studies (RR: } 0.43,95 \% \mathrm{Cl}: 0.30-0.63 \text { ) } \\
\text { DRZ is associated with a statistically significant risk } \\
\text { reduction for most cardiotoxic outcomes }\end{array}$ & [21] \\
\hline $\begin{array}{l}\text { Meta-analysis ( } 14 \\
\text { studies; } \\
2015 \text { patients) }\end{array}$ & $\begin{array}{l}1175 \text { patients with cancer treated } \\
\text { with cardioprotective agents } \\
7 \text { studies investigated DRZ ( } 6 \\
\text { studies in patients with breast } \\
\text { cancer (one of which included } \\
\text { patients with soft tissue sarcoma) } \\
\text { and } 1 \text { study in children with } \\
\text { Ewing sarcoma) } \\
\text { Enrollment required a normal EF } \\
\text { and no history of HF }\end{array}$ & $\begin{array}{l}\text { Patients received either a } \\
\text { prophylactic cardioprotective } \\
\text { intervention or control in } \\
\text { addition to chemotherapy }\end{array}$ & $\begin{array}{l}\text { Cardiac events were reduced with DRZ (RR: } 0.35,95 \% \mathrm{Cl} \text { : } \\
0.27-0.45 ; \mathrm{p}<0.001 \text { ) } \\
\text { Cardioprotective treatment with DRZ, beta-blockers, statins } \\
\text { or angiotensin antagonists appeared to have similar efficacy }\end{array}$ & {$[20]$} \\
\hline $\begin{array}{l}\text { Meta-analysis ( } 16 \\
\text { studies; } \\
1918 \text { patients) }\end{array}$ & $\begin{array}{l}\text { Adult cancer patients (mainly } \\
\text { breast cancer) }\end{array}$ & $\begin{array}{l}\text { Any cardioprotective agent was } \\
\text { compared with no additional } \\
\text { therapy or placebo in cancer } \\
\text { patients receiving anthracyclines }\end{array}$ & $\begin{array}{l}\text { DRZ reduced cardiotoxicity (composite of HF or decline in } \\
\text { LVEF): median pooled OR: } 0.26,95 \% \mathrm{Crl}: 0.11-0.73 \\
\text { HF: OR: } 0.12,95 \% \mathrm{Crl}: 0.06-0.23 \\
\text { LVEF: OR: } 0.17,95 \% \mathrm{Crl}: 0.09-0.39\end{array}$ & [19] \\
\hline \multicolumn{5}{|c|}{$\begin{array}{l}\text { †Dose ratio DRZ:anthracycline. } \\
\text { ¥Results from the P9754 trial were also included in the abstract. The results from this trial were published subsequently in reference [14]. } \\
\text { §In study 95-01 patients were randomly assigned to receive or not receive DRZ and in study 00-01 all high-risk patients received DRZ. } \\
\text { ALL: Acute lymphoblastic leukemia; AML: Acute myelogenous leukemia; Crl: Bayesian credible interval; DFCI: Dana-Farber Cancer Institute; DOX: Doxorubicin; DRZ: Dexrazoxane; } \\
\text { EF: Ejection fraction; FS z-score: Fractional shortening z-score; HF: Heart failure; HL: Hodgkin lymphoma; LB-NHL: Lymphoblastic non-Hodgkin lymphoma; LV: Left ventricular; LVEF: } \\
\text { Left ventricular ejection fraction; OR: Odds ratio; RCT: Randomized controlled trial; RR: Relative risk; SD: Standard deviation; TD z-score: Thickness-to-dimension z-score; T-ALL: T-cell } \\
\text { acute lymphoblastic leukemia; WT z-score: Wall thickness z-score. }\end{array}$} \\
\hline
\end{tabular}

AML rates of $0.21 \%$ in dexrazoxane-exposed and $0.55 \%$ in dexrazoxane-unexposed patients [15]. Dexrazoxane was not associated with an increased risk of AML (OR: 0.38, 95\% CI: 0.11-1.26) (Table 2). In a subgroup analysis of patients with lymphoma, the secondary AML rate did not differ between dexrazoxane-exposed and dexrazoxaneunexposed patients $(0.87$ and $0.56 \%$, respectively; $\mathrm{p}=0.67)$. The findings from this large study are consistent with a pooled analysis of 553 children with high- or very-high-risk ALL who all received dexrazoxane (DFCI 95-01, 00-01 and 05-01) [17]. In this study, the overall estimated mean (standard deviation [SD]) 5-year incidence of SPMs was $0.24 \%(0.24 \%)$ after a median follow up of 3.8 years (Table 2). The authors concluded that SPMs were rare in these children and recommended the continued use of dexrazoxane.

Of the 537 participants in the COG P9404 trial treated with chemotherapy and cranial radiation, SPMs were diagnosed in 11 patients, eight of $273(2.9 \%)$ patients who had received dexrazoxane and three of $264(1.1 \%)$ patients who had not (Table 2) [6]. Secondary brain tumors occurred in five (1.8\%) patients who had received dexrazoxane and in none of 264 patients who had not. The mean (standard error) 5-year cumulative incidence rates for SPMs were $0.8 \%(0.5 \%)$ and $0.7 \%(0.5 \%)$ for patients treated without and with dexrazoxane, respectively $(\mathrm{p}=0.17)$. At 10 years, the mean (standard error) cumulative rates were $1.2 \%(0.7 \%)$ and $1.8 \%(0.9 \%)$, respectively. A similar 5-year cumulative SPM incidence of $0.4 \%$ was found in the COG P9754 study (Table 2) [14]. Two patients experienced secondary leukemia, and only one of these was a first event. In addition, a report from the DFCI found no secondary brain tumors after dexrazoxane therapy among patients with ALL treated with cranial radiation (DFCI 95-01, 00-01 and 05-01) [17].

A pooled analysis from three COG randomized trials (P9404, T-cell ALL/lymphoma [n = 537]; P9425, intermediate/high-risk Hodgkin lymphoma [ $\mathrm{n}=216]$; and P9426, low-risk Hodgkin lymphoma [ $\mathrm{n}=255]$ ), in which 1008 children received doxorubicin, with or without dexrazoxane, attributed 18 deaths to SPMs (ten in the dexrazoxane group), indicating that dexrazoxane was not associated with death from secondary cancer [7]. Of the 18 deaths, 12 were from AML/MDS (seven in the dexrazoxane group), which corresponded to 10-year AML/MDS mortality rates of $1.4 \%$ with dexrazoxane and $0.8 \%$ without dexrazoxane (hazard ratio [HR]: 1.39 , 
Table 2. Studies of second malignancies in children and adolescents with hematological or solid tumors receiving anthracycline-based chemotherapy published after 1 January 2011.

\begin{tabular}{|c|c|c|c|c|}
\hline Study design and reference & Patients & $\begin{array}{l}\text { Anthracycline (DOX) and } \\
\text { dexrazoxane (DRZ) doses and } \\
\text { sample sizes }\end{array}$ & Results and comments & Ref. \\
\hline $\begin{array}{l}\text { Retrospective cohort } \\
\text { database analysis }\end{array}$ & $\begin{array}{l}15,532 \text { children with newly } \\
\text { diagnosed cancer other than } \\
\text { AML exposed to anthracyclines } \\
\text { (Pediatric Health Information } \\
\text { System Database) }\end{array}$ & $\begin{array}{l}\text { All children received anthracyclines } \\
\text { and } 1406 \text { were exposed to DRZ } \\
\text { Cumulative DOX dose: not stated }\end{array}$ & $\begin{array}{l}\text { Secondary AML. DRZ: } 0.21 \text { vs } 0.55 \% \text { in the } \\
\text { anthracycline-only group } \\
\text { DRZ was not associated with an increased risk of } \\
\text { secondary AML (OR: } 0.38,95 \% \mathrm{Cl}: 0.11-1.26 \text { ) }\end{array}$ & [15] \\
\hline $\begin{array}{l}\text { Prospective } \\
\text { partially randomized } \ddagger \\
\text { DFCI } 95-01, \text { DFCI 00-01, DFCI } \\
\text { 05-01; pooled analysis }\end{array}$ & $\begin{array}{l}\text { ALL (high- or very-high-risk) } \\
\leq 17 \text { years; median age } 10 \text { years }\end{array}$ & $\begin{array}{l}\text { DOX: } 30 \mathrm{mg} / \mathrm{m}^{2} / \text { infusion with DRZ } \\
(10: 1)^{\dagger}(\mathrm{n}=553) \\
\text { Cumulative DOX dose: } 300 \mathrm{mg} / \mathrm{m}^{2}\end{array}$ & $\begin{array}{l}\text { The overall estimated mean (SD) } 5 \text {-year } \\
\text { cumulative incidence of SPMs was } 0.24 \%(0.24 \%) \text {, } \\
95 \% \text { Cl: } 0.02-1.29 \% \text {. The only SPM was a case of } \\
\text { AML } \\
\text { SPMs were rare in these children and the } \\
\text { continued use of DRZ in these patients was } \\
\text { recommended }\end{array}$ & [17] \\
\hline $\begin{array}{l}\text { Randomized } \\
\text { COG P9404 }\end{array}$ & T-ALL or LB-NHL $\leq 22$ years & $\begin{array}{l}\text { Treatment details published in [23] } \\
\text { DOX: } 30 \mathrm{mg} / \mathrm{m}^{2} / \text { infusion with } \\
(\mathrm{n}=273) \text { or without }(\mathrm{n}=264) \text { DRZ } \\
(10: 1)^{\dagger} \\
\text { Cumulative DOX dose: } 360 \mathrm{mg} / \mathrm{m}^{2}\end{array}$ & $\begin{array}{l}\text { SPMs were diagnosed in } 11 \text { patients, } 8 \text { of whom } \\
\text { had received DRZ } \\
\text { The } 5 \text {-year mean (SD) cumulative incidence rates } \\
\text { for SPMs were } 0.8 \%(0.5 \%) \text { and } 0.7 \%(0.5 \%) \text { for } \\
\text { the no-DRZ and DRZ groups, respectively }(p=0.17) \\
\text { The } 10 \text {-year mean (SD) cumulative incidence rates } \\
\text { for SPMs were } 1.2 \%(0.7 \%) \text { and } 1.8 \%(0.9 \%) \text { for } \\
\text { the no-DRZ and DRZ groups, respectively } \\
\text { DRZ was not associated with the occurrence of } \\
\text { SPMs }\end{array}$ & [6] \\
\hline $\begin{array}{l}\text { Noncomparative } \\
\text { COG P9754 }\end{array}$ & $\begin{array}{l}\text { Osteosarcoma }<31 \text { years old } \\
\text { (median age } 13 \text { to } 14 \text { years old) }\end{array}$ & $\begin{array}{l}\text { DOX: } 37.5 \mathrm{mg} / \mathrm{m}^{2} / \text { infusion plus DRZ: } \\
375 \mathrm{mg} / \mathrm{m}^{2}(10: 1)^{\dagger}(\mathrm{n}=242) \\
\text { Cumulative DOX dose: } 600 \mathrm{mg} / \mathrm{m}^{2}\end{array}$ & $\begin{array}{l}\text { Cumulative incidence for SPMs was } 0.4 \% \\
\text { Two patients experienced secondary leukemia } \\
\text { (one case of juvenile myelomonocytic leukemia } \\
\text { and one case of AML) and only one of these was a } \\
\text { first event (juvenile myelomonocytic leukemia) } \\
\text { No evidence of an increased risk for secondary } \\
\text { leukemia }\end{array}$ & {$[14]$} \\
\hline $\begin{array}{l}\text { Randomized } \\
\text { COG P9404, P9425, P9426; } \\
\text { pooled analysis }\end{array}$ & $\begin{array}{l}\text { T-ALL/lymphoma }(n=537) \\
\text { intermediate/high-risk HL } \\
(n=216) \text {, low-risk } \mathrm{HL}(n=255) \\
\leq 22 \text { years }\end{array}$ & $\begin{array}{l}\text { DOX: } 25-30 \mathrm{mg} / \mathrm{m}^{2} / \text { infusion with } \\
(\mathrm{n}=507) \text { or without }(\mathrm{n}=501) \mathrm{DRZ} \\
(10: 1)^{\dagger} \\
\text { Cumulative DOX dose: } \\
100-360 \mathrm{mg} / \mathrm{m}^{2}\end{array}$ & $\begin{array}{l}18 \text { deaths were attributed to second cancers; } \\
10 \text { patients received DOX plus DRZ and } 8 \text { received } \\
\text { DOX alone (HR: } 1.24,95 \% \mathrm{Cl}: 0.49-3.15 \text { ) } \\
\text { Of the } 18 \text { deaths, } 12 \text { were from AML/MDS } \\
\text { ( } 7 \text { patients received DRZ) } \\
10 \text {-year cumulative incidences of AML/MDS: } 1.4 \% \\
\text { (DRZ plus DOX) and } 0.8 \% \text { (DOX; difference: } 0.6 \% \text {, } \\
95 \% \text { Cl: }-0.7 \text { to } 1.9 \% ; \mathrm{HR}: 1.39,95 \% \mathrm{Cl}: 0.44-4.37 \text { ) } \\
\text { The risk of mortality from secondary cancer was } \\
\text { not significantly higher in the patients who } \\
\text { received DRZ }\end{array}$ & [7] \\
\hline Nonrandomized & $\begin{array}{l}\text { Nonmetastatic limb } \\
\text { osteosarcoma }(n=26)<22 \text { years }\end{array}$ & $\begin{array}{l}\text { DOX: } 30 \mathrm{mg} / \mathrm{m}^{2} \text { infusion for } \\
3 \text { days + DRZ } 300 \mathrm{mg} / \mathrm{m}^{2} \text { on the first } \\
\text { day } \\
\text { Cumulative DOX dose: } 360 \mathrm{mg} / \mathrm{m}^{2}\end{array}$ & 2 of $26(7.6 \%)$ patients developed SPMs & [18] \\
\hline $\begin{array}{l}\text { Meta-analysis ( } 17 \text { studies; } \\
4639 \text { patients) }\end{array}$ & $\begin{array}{l}\text { Children with cancer treated } \\
\text { with DRZ as a cardioprotectant } \\
\text { Most patients in each included } \\
\text { study had to be }<18 \text { years old }\end{array}$ & $\begin{array}{l}\text { Anthracycline alone or combined } \\
\text { with DRZ (10:1 to } 20: 1)^{\dagger} \\
\text { Mean/median cumulative } \\
\text { anthracycline dose in some of the } \\
\text { included studies was }<300 \mathrm{mg} / \mathrm{m}^{2} \\
\text { equivalent doxorubicin dose }\end{array}$ & $\begin{array}{l}\text { In RCTs, } 17 \text { SPMs were discovered in } 635(2.7 \%) \\
\text { patients who had received DRZ and } 7 \text { SPMs were } \\
\text { identified in } 619(1.1 \%) \text { patients unexposed to } \\
\text { DRZ (RR: } 2.37 ; p=0.06) \text {. The types of SPMs varied } \\
\text { In nonrandomized studies, } 7 \text { SPMs were diagnosed } \\
\text { in } 860(0.8 \%) \text { patients who had received DRZ and } \\
18 \text { SPMs were identified in } 1825(1.0 \%) \text { patients } \\
\text { who had not received DRZ ( } p=0.72) \\
\text { DRZ use was associated with a statistically } \\
\text { borderline increase in SPMs, although an } \\
\text { interaction with concurrent cancer therapies may } \\
\text { have caused this result }\end{array}$ & [21] \\
\hline \multicolumn{5}{|c|}{$\begin{array}{l}\text { †Dose ratio DRZ:anthracycline. } \\
\text { † In study 95-01 patients were randomly assigned to receive or not receive DRZ and in studies 00-01 and 05-01 all high-risk and very high-risk patients received DRZ. } \\
\text { § Results from the COG P9754 trial were also included in the abstract. The results from this trial were published subsequently in reference [14]. } \\
\text { ALL: Acute lymphoblastic leukemia; AML: Acute myeloid leukemia; DFCl: Dana-Farber Cancer Institute; DOX: Doxorubicin; DRZ: Dexrazoxane; HL: Hodgkin lymphoma; HR: Hazard } \\
\text { ratio; LB-NHL: Lymphoblastic non-Hodgkin lymphoma; MDS: Myelodysplastic syndrome; OR: Odds ratio; RCT: Randomized controlled trial; RR: Relative risk; SD: Standard deviation; } \\
\text { SPM: Second primary malignancy; T-ALL: T-cell acute lymphoblastic leukemia. }\end{array}$} \\
\hline
\end{tabular}


95\% CI: 0.44-4.37; Table 2). Two deaths from new non-Hodgkin lymphomas (one in the dexrazoxane group) and four deaths from other new solid tumors (two in the dexrazoxane group) were also reported. When all 13 patients with incident AML/MDS were considered, not just those who died, the HR associated with dexrazoxane was 2.21 (95\% CI: 0.68-7.18; $\mathrm{p}=0.19$ ).

The 2016 meta-analysis by Shaikh and colleagues found that the difference in incidence of SPMs in children receiving dexrazoxane as part of a randomized controlled trial $(2.7 \%)$ compared with those in the control arm $(1.1 \%)$ approached significance $(\mathrm{p}=0.06)$ (Table 2) [21]. However, the rate of AML or MDS was increased only in the two COG trials (P9425 and P9426) that administered etoposide with doxorubicin and dexrazoxane (the pooled mean [SD] 4-year incidence rate for AML/MDS was 2.55\% [1.0\%] with dexrazoxane and 0.85\% [0.6\%] without dexrazoxane; $\mathrm{p}=0.16$ ) [21,24]. When these two studies were removed from the analysis, the rates of AML did not differ in the remaining patients (two of 401 patients treated with dexrazoxane and two of 382 patients without; $\mathrm{p}=0.97$ ) [21]. This meta-analysis also reported seven SPMs in 860 children who had received dexrazoxane and 18 SPMs in 1825 children who had not in four nonrandomized studies $(\mathrm{p}=0.72)$ [21].

In summary, the clinical evidence obtained since 2011 does not support the conclusion that dexrazoxane exposure is associated with an increased risk of SPMs.

Dexrazoxane may be associated with specific but reversible toxicities, including myelosuppression

Given the nature of the cancers being treated and the therapies being tested, ascribing causality for differences in tolerability, safety and toxicity is complex. The overall tolerability and safety of dexrazoxane has been established in extensive reviews $[22,28]$. Several recent investigations highlighted the incidence of adverse hematological events in children after dexrazoxane treatment (Table 3) $[6,8,12,14,16]$. The COG P9404 trial found similar rates of infection, hematologic toxicity and central nervous system toxicity in patients who did and did not receive dexrazoxane [6]. The only grade $3 / 4$ event to differ significantly between groups was mucositis, which had a lower incidence in the dexrazoxane group (33/273 [12.1\%] patients) than in the no-dexrazoxane group (52/264 [19.7\%] patients; $\mathrm{p}=0.02)$. Other nonrandomized studies have reported adverse hematological events after dexrazoxane treatment $[8,12,14,16]$. Despite the hematological toxicity observed in some studies, overall treatment with dexrazoxane appears to be well tolerated. In the P9754 study, therapeutic intensification was achieved with acceptable toxicity [14].

\section{Dexrazoxane is not associated with excess mortality}

In the 2011 CHMP referral, a possible association between dexrazoxane and a higher incidence of death was noted, based on reports of higher early death rates in the dexrazoxane arms of three US randomized trials [1]. However, several recently published investigations do not substantiate these concerns (Table 4). A pooled mortality analysis of the long-term overall and cause-specific mortality from three randomized COG studies (P9404, P9425 and P9426) showed that dexrazoxane did not significantly affect 10-year mortality (HR: 1.03, 95\% CI: 0.73-1.45). Similar findings were observed in each trial separately [7]. Dexrazoxane did not affect overall survival in the P9404 trial $(\mathrm{p}=0.90)$ [6]. For all 537 patients, mean $(\mathrm{SD})$ overall 5 - and 10 -year survival rates were $82.1 \%(1.7 \%)$ and $80.6 \%(2.4 \%)$, respectively. Taken together, these studies suggest that dexrazoxane does not increase mortality in patients treated with anthracyclines. The meta-analysis by Shaikh and colleagues of randomized trials involving children also showed that overall survival was not affected by dexrazoxane use (HR: 0.85, 95\% CI: 0.44-1.64; $\mathrm{p}=0.63)[21]$.

\section{Dexrazoxane does not impair the antitumor efficacy of anthracyclines}

One old randomized trial in women with breast cancer reported a statistically significant lower response rate in women treated with dexrazoxane than in those treated without (trial 088001) [30]. However, time to progression and overall survival did not differ significantly between the two treatment groups in this trial. None of the three recently published studies suggest that dexrazoxane compromises the efficacy of chemotherapy (Including data from COG P9404, P9425, P9426 and DFCI 95-01 trials) [6,7,31]. In the P9404 trial, event-free survival did not differ between the dexrazoxane and no-dexrazoxane groups $(\mathrm{p}=0.86)$ (Table 5) [6].

In all patients, mean (SD) 5- and 10-year event-free survival rates were $76.4 \%(1.9 \%)$ and $75.2 \%(2.6 \%)$, respectively. Similarly, event-free survival did not differ between the dexrazoxane and no-dexrazoxane groups in the DFCI 95-01 trial $(\mathrm{p}=0.99)$ (Table 5) [31]. Furthermore, pooled analysis of the three COG trials (P9404, P9425 and P9426) revealed that dexrazoxane was not associated with an increased hazard of relapse (HR: 0.81, 


\begin{tabular}{|c|c|c|c|c|}
\hline Study design & Patients & $\begin{array}{l}\text { Anthracycline (DOX) and } \\
\text { dexrazoxane (DRZ) doses and } \\
\text { sample sizes }\end{array}$ & Results and comments & Ref. \\
\hline $\begin{array}{l}\text { Randomized } \\
\text { COG P9404 }\end{array}$ & T-ALL or LB-NHL $\leq 22$ years & $\begin{array}{l}\text { Treatment details published in [23] } \\
\text { DOX: } 30 \mathrm{mg} / \mathrm{m}^{2} / \text { infusion with } \\
(\mathrm{n}=273) \text { or without }(\mathrm{n}=264) \text { DRZ } \\
(10: 1)^{\dagger} \\
\text { Cumulative DOX dose: } 360 \mathrm{mg} / \mathrm{m}^{2}\end{array}$ & $\begin{array}{l}\text { Rates of grade } 3 / 4 \text { hematologic toxicity were } \\
\text { similar in the DOX alone }(237 / 264,89.8 \%) \text { and } \\
\text { DOX plus DRZ }(243 / 273,89.0 \%) \text { groups }(p=0.26) \\
\text { DRZ did not increase the frequency of } \\
\text { hematological toxicities }\end{array}$ & [6] \\
\hline $\begin{array}{l}\text { Phase II } \\
\text { Noncomparative }\end{array}$ & $\begin{array}{l}\text { Osteosarcoma } \\
<32 \text { years old (mean age: } \\
14.5 \text { years) }\end{array}$ & $\begin{array}{l}\text { DOX: } 37.5 \mathrm{mg} / \mathrm{m}^{2} / \text { infusion with DRZ } \\
(10: 1)^{\dagger}(\mathrm{n}=96) \\
\text { Cumulative DOX dose: } 375 \mathrm{mg} / \mathrm{m}^{2}\end{array}$ & $\begin{array}{l}\text { "As expected the regimen was myelosuppressive } \\
\text { with nearly all patients developing grade } 3 \text { or } 4 \\
\text { neutropenia and the vast majority requiring } \\
\text { blood product support" }\end{array}$ & [8] \\
\hline $\begin{array}{l}\text { Noncomparative } \\
\text { COG P9754 }\end{array}$ & $\begin{array}{l}\text { Osteosarcoma } \\
<31 \text { years old (median age } \\
13-14 \text { years) }\end{array}$ & $\begin{array}{l}\text { DOX: } 37.5 \mathrm{mg} / \mathrm{m}^{2} / \text { infusion plus DRZ: } \\
375 \mathrm{mg} / \mathrm{m}^{2}(10: 1)^{\dagger}(n=242) \\
\text { Cumulative DOX dose: } 600 \mathrm{mg} / \mathrm{m}^{2}\end{array}$ & $\begin{array}{l}\text { Most common hematological grade } 3 / 4 \text { toxicities: } \\
\text { neutrophils/granulocytes: } 92(74.8 \%) \text { patients in } \\
\text { pilot study } 1 \text { and } 87(73.7 \%) \text { patients in pilot } \\
\text { studies } 2 \text { and } 3 \\
\text { Leukocytes (total WBC): } 68(55.3 \%) \text { patients in } \\
\text { pilot study } 1 \text { and } 79(66.9 \%) \text { patients in pilot } \\
\text { studies } 2 \text { and } 3 \\
\text { Hemoglobin: } 59(48.0 \%) \text { patients in pilot study } 1 \\
\text { and } 46(39.0 \%) \text { patients in pilot studies } 2 \text { and } 3 \\
\text { Platelets: } 52(42.3 \%) \text { patients in pilot study } 1 \text { and } \\
47(39.8 \%) \text { patients in pilot studies } 2 \text { and } 3 \\
\text { Therapeutic intensification was achieved with } \\
\text { acceptable toxicity }\end{array}$ & [14] \\
\hline $\begin{array}{l}\text { Phase I } \\
\text { Noncomparative }\end{array}$ & $\begin{array}{l}\text { Extracranial nonhematopoietic } \\
\text { solid tumors } \leq 21 \text { years }\end{array}$ & $\begin{array}{l}\text { DOX: } 20-25 \mathrm{mg} / \mathrm{m}^{2} / \text { infusion with } \\
\text { DRZ }(10: 1)^{\dagger}(\mathrm{n}=96) \\
\text { Cumulative DOX dose: } 750 \mathrm{mg} / \mathrm{m}^{2}\end{array}$ & $\begin{array}{l}\text { Dose-limiting grade } 4 \text { thrombocytopenia was } \\
\text { observed in } 2 \text { of } 5(40 \%) \text { patients who received } \\
20 \mathrm{mg} / \mathrm{m}^{2} \text { DOX plus } 130 \mathrm{mg} / \mathrm{m}^{2} \text { oxaliplatin } \\
\text { Dose-limiting grade } 2 \text { cardiac toxicity and grade } 4 \\
\text { thrombocytopenia were both observed in } 1 \text { of } \\
5 \text { patients who received } 25 \mathrm{mg} / \mathrm{m}^{2} \text { DOX plus } \\
130 \mathrm{mg} / \mathrm{m}^{2} \text { oxaliplatin } \\
\text { No dose-limiting grade } 3 \text { or } 4 \text { neurotoxicity or } \\
\text { mucositis was seen } \\
\text { Cardiac and hematological toxicity were the } \\
\text { dose-limiting toxicities }\end{array}$ & [12] \\
\hline $\begin{array}{l}\text { Phase II } \\
\text { Retrospective } \\
\text { Noncomparative }\end{array}$ & $\begin{array}{l}\text { High-risk neuroblastoma } \\
\leq 18 \text { years }\end{array}$ & $\begin{array}{l}\text { DOX: } 60-75 \mathrm{mg} / \mathrm{m}^{2} / \text { infusion with } \\
\text { DRZ }(10: 1)^{\dagger}(\mathrm{n}=7) \\
\text { Cumulative DOX dose: } 540 \mathrm{mg} / \mathrm{m}^{2}\end{array}$ & $\begin{array}{l}\text { Prolonged thrombocytopenia causing treatment } \\
\text { delay was observed when oxaliplatin was } \\
\text { administered at } 130 \mathrm{mg} / \mathrm{m}^{2, b} \\
\text { Four additional patients were treated at the } \\
\text { maximum tolerated dose }\left(60 \mathrm{mg} / \mathrm{m}^{2} \text { DOX plus }\right. \\
105 \mathrm{mg} / \mathrm{m}^{2} \text { oxaliplatin). Grade } 4 \\
\text { thrombocytopenia occurred in } 4 \text { of } 10 \text { courses } \\
\text { administered with no delays in treatment }{ }^{\ddagger} \text { Grade } \\
4 \text { neutropenia and grade } 3 \text { febrile neutropenia } \\
\text { were observed in } 3 \text { courses } \\
\text { The maximum tolerated dose of DOX and } \\
\text { oxaliplatin was well tolerated }\end{array}$ & [16] \\
\hline \multicolumn{5}{|c|}{$\begin{array}{l}\text { †Dose ratio DRZ:anthracycline. } \\
\text { ¥Thrombocytopenia is a common toxicity of oxaliplatin treatment [29]. } \\
\text { AE: Adverse event; ANC: Absolute neutrophil count; DOX: Doxorubicin; DRZ: Dexrazoxane; EPI: Epirubicin; HL: Hodgkin lymphoma; LB-NHL: Lymphoblastic non-Hodgkin lymphoma; } \\
\text { RR: Relative risk; T-ALL: T-cell acute lymphoblastic leukemia; WBC: White blood cell. }\end{array}$} \\
\hline
\end{tabular}

95\% CI: 0.60-1.08) (Table 5) [7]. In the 2016 meta-analysis by Shaikh and colleagues [21], event-free survival did not differ significantly between treatment and controls (HR: 0.99, 95\% CI: 0.78-1.25; p = 0.91). Collectively, these results indicate that the concomitant use of dexrazoxane and anthracycline-containing regimens does not reduce the efficacy of chemotherapy.

\section{Discussion}

Over the past 40 years, chemotherapeutic agents, including anthracyclines, have markedly improved clinical outcomes for patients with different types of hematological and solid cancers. This improvement is possibly best exemplified in children, in whom 5-year survival rates more than doubled during this period [32-35]. Today, more patients treated for cancer can expect to achieve a relatively normal lifespan, a success that brings with it a distinct set of problems. 


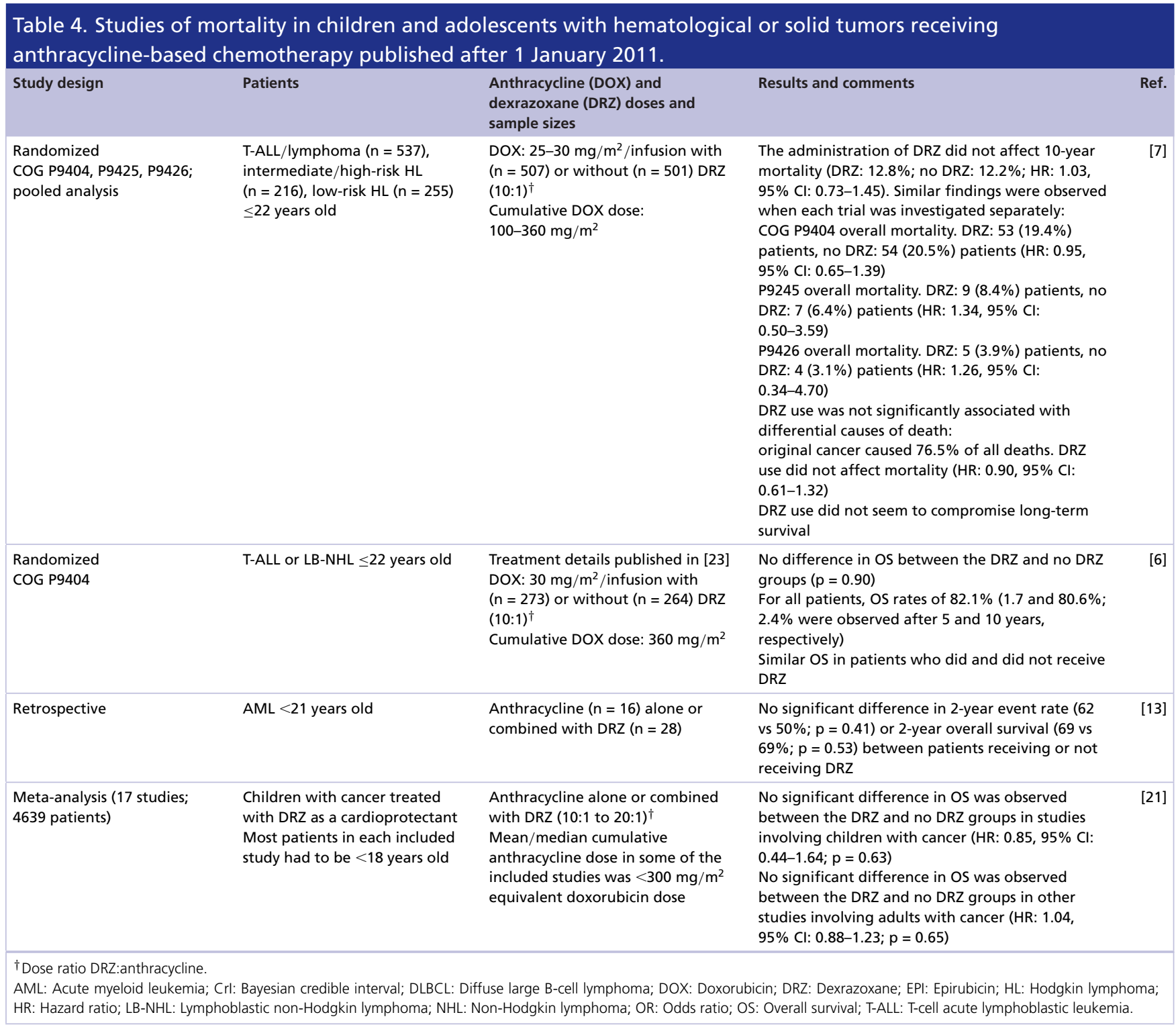

Unlike treatments for many other debilitating diseases that do not affect long-term health, the delayed effects of chemotherapy and radiotherapy often accompany improved survival [33,36]. In cancer survivors, many organ systems may be affected by the long-term complications of therapy. After cancer relapse and SPMs, cardiovascular-related problems are the leading cause of morbidity and mortality in survivors $[37,38]$. The potentially life-threatening cardiotoxic effects of anthracycline-based chemotherapy in these patients clearly need to be reduced. Although immunotherapy and targeted therapies are promising [39,40], anthracycline treatment remains necessary for many children and adults with cancer.

Cardioprotection is desirable for any patient receiving anthracyclines because even very low doses can cause subclinical cardiotoxicity [41]. Several strategies can reduce the cardiac sequelae of anthracyclines in adults, including using continuous infusion rather than bolus administration, liposomal doxorubicin, beta-blockers and angiotensin converting enzyme inhibitors [42-47]. Despite these strategies, dexrazoxane is the only agent proven to protect against anthracycline-related cardiotoxicity over extended periods [32,48]. The newer evidence summarized here documents the early cardioprotective properties of dexrazoxane in children with various cancers who received anthracyclinecontaining chemotherapy. The extensive data published since 2011 consistently demonstrates that dexrazoxane is an efficacious cardioprotectant in children. Furthermore, a meta-analysis of randomized trials by the Cochrane Group (ten studies on dexrazoxane; 1619 patients) that predominantly involved women with advanced breast 


\begin{tabular}{|c|c|c|c|c|}
\hline Study design & Patients & $\begin{array}{l}\text { Anthracycline (DOX) and } \\
\text { dexrazoxane (DRZ) doses and } \\
\text { sample sizes }\end{array}$ & Results and comments & Ref. \\
\hline $\begin{array}{l}\text { Randomized } \\
\text { COG P9404 }\end{array}$ & T-ALL or LB-NHL $\leq 22$ years old & $\begin{array}{l}\text { Treatment details published in [23] } \\
\text { DOX: } 30 \mathrm{mg} / \mathrm{m}^{2} / \text { infusion with } \\
(\mathrm{n}=273) \text { or without }(\mathrm{n}=264) \text { DRZ } \\
(10: 1)^{\dagger} \\
\text { Cumulative DOX dose: } 360 \mathrm{mg} / \mathrm{m}^{2}\end{array}$ & $\begin{array}{l}\text { No difference in EFS between the DRZ and no DRZ } \\
\text { groups ( } p=0.86 \text { ) } \\
\text { For all patients, EFS rates of } 76.4 \% \text { ( } 1.9 \text { and } \\
75.2 \% ; 2.6 \% \text { were observed after } 5 \text { and } 10 \text { years, } \\
\text { respectively) } \\
\text { Similar EFS in patients who did and did not } \\
\text { receive DRZ }\end{array}$ & [6] \\
\hline Randomized DFCI 95-01 & ALL (high risk) $<18$ years old & $\begin{array}{l}\text { DOX: } 30 \mathrm{mg} / \mathrm{m}^{2} / \text { infusion with } \\
(n=105) \text { or without }(\mathrm{n}=100) \mathrm{DRZ} \\
(10: 1)^{\dagger} \\
\text { Cumulative DOX dose: } 300 \mathrm{mg} / \mathrm{m}^{2}\end{array}$ & $\begin{array}{l}\text { No difference in EFS between the DRZ }(76 \% \text {, } \\
95 \% \mathrm{Cl}: 67-84) \text { and no DRZ }(77 \%, 95 \% \mathrm{Cl}: 67-84) \\
\text { groups }(\mathrm{p}=0.99) \text { at a median follow-up of } \\
8.7 \text { years }\end{array}$ & [31] \\
\hline $\begin{array}{l}\text { Randomized } \\
\text { COG P9404, P9425, P9426; } \\
\text { pooled analysis }\end{array}$ & $\begin{array}{l}\text { T-ALL/lymphoma }(n=537) \\
\text { intermediate/high-risk HL } \\
(n=216) \text {, low-risk HL }(n=255) \\
\leq 22 \text { years old }\end{array}$ & $\begin{array}{l}\text { DOX: } 25-30 \mathrm{mg} / \mathrm{m}^{2} / \text { infusion with } \\
(\mathrm{n}=507) \text { or without }(\mathrm{n}=501) \mathrm{DRZ} \\
(10: 1)^{\dagger} \\
\text { Cumulative DOX dose: } \\
100-360 \mathrm{mg} / \mathrm{m}^{2}\end{array}$ & $\begin{array}{l}\text { DZR was not associated with an increased risk of } \\
\text { relapse (HR: } 0.81,95 \% \mathrm{Cl}: 0.60-1.08 \text { ) } \\
\text { 10-year cumulative incidence of relapse DRZ } \\
\text { group: } 16.1 \% \text {; no DRZ group } 19.1 \% \text { (difference: } \\
-3.0 \%, 95 \% \mathrm{Cl}:-7.9-0.2 \% \text { ) }\end{array}$ & [7] \\
\hline $\begin{array}{l}\text { Meta-analysis ( } 17 \text { studies; } \\
4639 \text { patients) }\end{array}$ & $\begin{array}{l}\text { Children with cancer treated } \\
\text { with DRZ as a cardioprotectant } \\
\text { Most patients in each included } \\
\text { study had to be }<18 \text { years old }\end{array}$ & $\begin{array}{l}\text { Anthracycline alone or combined } \\
\text { with DRZ (10:1 to } 20: 1)^{\dagger} \\
\text { Mean/median cumulative } \\
\text { anthracycline dose in some of the } \\
\text { included studies was }<300 \mathrm{mg} / \mathrm{m}^{2} \\
\text { equivalent doxorubicin dose }\end{array}$ & $\begin{array}{l}\text { EFS did not differ between the DRZ and no DRZ } \\
\text { groups in studies involving children with cancer } \\
\text { (HR: } 0.99,95 \% \mathrm{Cl}: 0.78-1.25 ; \mathrm{p}=0.91 \text { ) } \\
\text { EFS did not differ between the DRZ and no DRZ } \\
\text { groups in other studies involving adults with } \\
\text { cancer (HR: } 1.01,95 \% \mathrm{Cl}: 0.86-1.18 ; \mathrm{p}=0.89 \text { ) }\end{array}$ & [21] \\
\hline \multicolumn{5}{|c|}{$\begin{array}{l}\text { †Dose ratio DRZ:anthracycline. } \\
\text { CR: Complete response; Crl: Bayesian credible interval; DOX: Doxorubicin; DRZ: Dexrazoxane; EFS: Event-free survival; HL: Hodgkin lymphoma; HR: Hazard ratio; LB-NHL: Lymphoblastic } \\
\text { non-Hodgkin lymphoma; NHL: Non-Hodgkin lymphoma; OR: Odds ratio; PFS: Progression-free survival; PR: Partial response; RR: Relative risk; T-ALL: T-cell acute lymphoblastic leukemia. }\end{array}$} \\
\hline
\end{tabular}

cancer but that included one study of children with leukemia, reported similar findings. This incidence of heart failure among patients receiving dexrazoxane plus anthracycline $(11 / 769,1.4 \%)$ was significantly lower than in patients receiving anthracycline alone (69/792,10\%; RR: 0.18, 95\% CI: 0.10-0.32; p < 0.001) [22].

The evidence for late cardioprotective effects is more preliminary because outcome data from patients with more than 5 years of follow-up are limited. Given the limited duration of follow-up and the progressive nature of cardiac dysfunction, extensive analyses of clinical outcomes have not been possible in the studies conducted thus far. We acknowledge that additional prospective longer-term studies are required to determine the impact of dexrazoxane on specific cardiac outcomes.

The perceived risk of SPMs with dexrazoxane use in children is based on the results of a single analysis by Tebbi and colleagues (COG P9425 and P9426) [24]. No study published since this 2007 analysis have confirmed this perceived risk $[6,7,14,15,17,18]$. Patients in the original report by Tebbi and colleagues received etoposide as part of their chemotherapy regimen. The only studies that showed a nonsignificant increase in the risk of SPMs since this publication also involved trials in which patients also received etoposide. The use etoposide may have contributed to the increased incidence of SPMs in the dexrazoxane arm in the Tebbi and colleagues analysis and combination therapies involving etoposide and dexrazoxane should therefore be viewed with caution.

The meta-analysis by the Cochrane Group in predominantly adult patients found three SPMs among $212(1.4 \%)$ patients randomly assigned to receive dexrazoxane and two among 209 (1.0\%) control patients (RR: 1.39, 95\% CI: $0.28-6.90 ; p=0.69$ [ [22]. These findings provide further evidence that dexrazoxane exposure is not associated with an increased risk of SPMs.

Our findings did confirm that adverse hematological events are common in children receiving chemotherapy and dexrazoxane; however, most of these trials were nonrandomized, preventing us from assessing the role of dexrazoxane in these events. The only randomized trial showed that the incidence of grade $3 / 4$ hematological toxicity was virtually identical in patients treated with $(89.0 \%)$ or without $(89.8 \%)$ dexrazoxane $(p=0.26)$ [6]. The myelosuppressive changes observed in nonrandomized studies $[8,12,14,16]$ may have been caused by the complex chemotherapy being administered. The Cochrane Group meta-analysis found no differences in the incidences of grade 3/4 thrombocytopenia, abnormal platelet counts (nadir or at recovery), neutropenia, abnormal granulocyte counts (nadir or at recovery) or white blood cell counts at recovery in patients treated with or without dexrazoxane [22]. However, grade $3 / 4$ white blood cell counts at nadir (RR: 1.16, 95\% CI: $1.05-1.29 ; \mathrm{p}=0.005$ ) and grade 3/4 
anemia (RR: $1.40,95 \%$ CI: 1.08-1.81; $\mathrm{p}=0.01$ ) were more common in the dexrazoxane groups. Given the range of myelosuppressive changes reported, it seems probable that hematological toxicity may be influenced by several factors, including the severity of the cancer, the type and dose of chemotherapy and the use of dexrazoxane and other treatments. The interplay among these factors clearly needs to be better understood. Best clinical practice should include routine hematological testing and blood product support when appropriate.

None of the studies published since 2011 indicate that dexrazoxane use affects overall survival in children. Two recent meta-analyses in predominantly adult populations also found no significant differences in overall survival between dexrazoxane and control groups [19,22].

We also found no evidence to suggest that dexrazoxane might impair the antitumor efficacy of anthracyclines in children. In the Cochrane Group meta-analysis, there was a trend toward a lower rate of partial or complete responses to treatment in patients randomly assigned to receive dexrazoxane $(223 / 503,44.3 \%)$ compared with control patients $(260 / 518,50.2 \% ; \mathrm{p}=0.08)$ [22]. However, progression-free survival did not differ between the two groups (HR: 1.01, 95\% CI: 0.86-1.18; $\mathrm{p}=0.89$ ), nor did response rates differ between dexrazoxane and control groups in another meta-analysis involving mainly women with breast cancer (OR: 1.21, 95\% CrI: 0.89-1.61) [19]. Altogether, these data provide substantial evidence that dexrazoxane does not reduce the efficacy of anthracyclines.

We did not find any evidence to support the remaining limitations for dexrazoxane, in particular, the decision of the CHMP to maintain the contraindication in children aged $0-18$ years who are expected to receive a cumulative dose of doxorubicin of less than $300 \mathrm{mg} / \mathrm{m}^{2}$, or the equivalent cumulative dose of another anthracycline. There is no safe dose of anthracyclines and myocyte injury appears to occur from the first dose [41,49]. Considering the safety profile of dexrazoxane reviewed here, and the fact that dexrazoxane does not reduce the efficacy of anthracyclines, it is reasonable to assume that all pediatric patients receiving anthracyclines would benefit from the cardioprotective effects of dexrazoxane.

\section{Conclusion}

The field of oncology has accepted the potential benefits of dexrazoxane by including it in both clinical practice guidelines and in treatment protocols. For example, both ESMO and ASCO recommend dexrazoxane for specific patients at risk of cardiotoxicity [50,51].

Since the 2011 CHMP appraisal, several new trials on the benefit-risk of dexrazoxane have been published. These trials, in conjunction with older trials, indicate that dexrazoxane is a well-tolerated and effective cardioprotectant when administered with anthracycline-containing chemotherapy. Recent studies show that dexrazoxane in cancer patients treated with anthracyclines is not associated with a clinically meaningful reduction in antitumor efficacy or reduced survival or a clinically relevant increased risk of SPMs. These studies contributed to the CHMP's decision to remove the contraindication on Cardioxane for children and adolescents with cancer whose planned treatment includes high cumulative doses of anthracyclines [3]. Although no new safety signals have been discovered in the recent literature, adverse hematological effects remain the most common problem in patients receiving relatively complex chemotherapeutic regimens. In light of these effects, the labeling for dexrazoxane requires routine peripheral blood monitoring in patients receiving dexrazoxane therapy.

\section{Future perspective}

The field of medical oncology will probably evolve quickly in the coming years, with the advent of immunotherapies and targeted therapies, whose long-term implications are not yet known. However, many patients, including children with sarcoma, acute leukemia or other malignancies, will still need anthracycline chemotherapy to be cured. Cardiotoxicity is a well-known side effect of anthracyclines, which can severely affect health years or even decades later. The advantages of dexrazoxane in providing cardioprotection to high-risk patients during treatment now offers new perspectives to preserve cardiac function in patients who require anthracycline chemotherapy.

\section{Author contributions}

All authors were involved in the analysis and interpretation of the data and the decision to submit this manuscript for publication.

\section{Acknowledgements}

The authors thank S Lipshultz for critically reviewing their manuscript prior to publication. S Lipshultz was a paid consultant to Clinigen. 
Financial \& competing interests disclosure

All authors disclose occasional consultancy work for Clinigen. P Reichardt has also served on advisory boards for Novartis, Pfizer, PharmaMar, Ariad, Merck, Deciphera, Roche, and Lilly, and has received honoraria from Novartis, Pfizer, Bayer, PharmaMar, and Lilly. R Jones has also acted as a consultant for Adaptimmune, Blueprint, Eisai, Epizyme, Daichii, Deciphera, Immunedesign, Lilly, Merck and Pharmamar. The authors have no other relevant affiliations or financial involvement with any organization or entity with a financial interest in or financial conflict with the subject matter or materials discussed in the manuscript apart from those disclosed.

Third-party writing assistance for this article was provided by Mike Parsons and Jamie Ashman of Prism Ideas and funded by Clinigen.

\section{Open access}

This work is licensed under the Attribution-NonCommercial-NoDerivatives 4.0 Unported License. To view a copy of this license, visit http://creativecommons.org/licenses/by-nc-nd/4.0/

\section{Executive summary}

The dexrazoxane label was restricted in 2011

- Dexrazoxane has been used to prevent anthracycline-related cardiotoxicity since the $1980 \mathrm{~s}$.

- Since 2011, the European indication for dexrazoxane has been restricted to women with breast cancer who had received a prior cumulative dose of $300 \mathrm{mg} / \mathrm{m}^{2}$ of doxorubicin (or $540 \mathrm{mg} / \mathrm{m}^{2}$ of epirubicin) when further anthracycline treatment was required, and it was contraindicated in children.

- These limitations were based on concerns that dexrazoxane might increase the risk of second primary malignancies, myelosuppression and infection, particularly in children.

In 2017, these restrictions were partially lifted considering more extensive data

- After reassessing the data in 2017, the CHMP limited the contraindication to children aged 0-18 years expected to receive a cumulative dose of less than $300 \mathrm{mg} / \mathrm{m}^{2}$ of doxorubicin or an equivalent dose of another anthracycline.

This review of the recent evidence leading to reassessing the European label for dexrazoxane found that:

- Dexrazoxane is an effective cardioprotectant in children and adolescents.

- Dexrazoxane is not associated with an increased risk of second primary malignancies.

- Dexrazoxane may be associated with specific but reversible toxicities, including myelosuppression.

- Dexrazoxane is not significantly associated with excess mortality.

- Dexrazoxane therapy does not impair anthracycline's antitumor efficacy.

\section{References}

Papers of special note have been highlighted as: $\bullet$ of interest; $\bullet \bullet$ of considerable interest

1. EMA. European Medicines Agency. Assessment report. Dexrazoxane-containing medicinal products (EMEA/H/A-31/1275). (2011). www.ema.europa.eu/docs/en_GB/document_library/Referrals_document/Dexrazoxane_31/WC500120340.pdf

2. CARDIOXANE SmPC. CARDIOXANE SmPC (2015). www.medicines.org.uk/emc/medicine/28199

3. EMA. European Medicines Agency. Questions and answers on Cardioxane (dexrazoxane: powder for solution for injection: $500 \mathrm{mg}$ ). Outcome of a procedure under Article 13 of Regulation (EC) No 1234/2008 (2017). www.ema.europa.eu/docs/en_GB/document_library/Referrals_document/Cardioxane_13/WC500228103.pdf

- Summarizes the CHMP's decision to remove the contraindication on Cardioxane for children and adolescents with cancer whose planned treatment includes high cumulative doses of anthracyclines.

4. European Commission. Commission Implementing Decision of 19.7.2017 concerning: in the framework of Article 13 of Commission Regulation (EC) No 1234/2008: the marketing authorisations for medicinal products for human use 'Cardioxane': which contain the active substance 'dexrazoxane'. C(2017) 5248 final (2017). ec.europa.eu/health/documents/community-register/2017/20170719138252/dec_138252_en.pdf

5. Walker DM, Fisher BT, Seif AE et al. Dexrazoxane use in pediatric patients with acute lymphoblastic or myeloid leukemia from 1999 and 2009: analysis of a national cohort of patients in the Pediatric Health Information Systems database. Pediatr. Blood Cancer 60(4), 616-620 (2013).

6. Asselin BL, Devidas M, Chen L et al. Cardioprotection and safety of dexrazoxane in patients treated for newly diagnosed T-cell acute lymphoblastic leukemia or advanced-stage lymphoblastic non-Hodgkin lymphoma: a report of the Children's Oncology Group Randomized Trial Pediatric Oncology Group 9404. J. Clin. Oncol. 34(8), 854-862 (2016).

-• This recent randomized trial from the Children's Oncology Group (P9404) showed that dexrazoxane significantly improved every investigated echocardiographic measure at 3 years in children with newly diagnosed T-cell acute lymphoblastic leukemia or 
lymphoblastic non-Hodgkin lymphoma. Dexrazoxane did not affect event-free survival, overall survival or the incidence of second primary malignancies.

7. Chow EJ, Asselin BL, Schwartz CL et al. Late mortality after dexrazoxane treatment: a report from the Children's Oncology Group. J. Clin. Oncol. 33(24), 2639-2645 (2015).

- This pooled analysis of three randomized trials from the Children's Oncology group (COG P9404, P9425 and P9426) indicated that dexrazoxane did not significantly affect 10-year mortality or relapse rates and was not associated with death from secondary cancer.

8. Ebb D, Meyers P, Grier H et al. Phase II trial of trastuzumab in combination with cytotoxic chemotherapy for treatment of metastatic osteosarcoma with human epidermal growth factor receptor 2 overexpression: a report from the Children's Oncology Group. J. Clin. Oncol. 30(20), 2545-2551 (2012).

9. Kang M, Kim KI, Song YC et al. Cardioprotective effect of early dexrazoxane use in anthracycline treated pediatric patients. J. Chemother. 24(5), 292-296 (2012).

10. Krajinovic M, Elbared J, Drouin $\mathrm{S}$ et al. Polymorphisms of $A B C C 5$ and NOS3 genes influence doxorubicin cardiotoxicity in survivors of childhood acute lymphoblastic leukemia. Pharmacogenomics J. 16(6), 530-535 (2016).

11. Lipshultz SE, Miller TL, Scully RE et al. Changes in cardiac biomarkers during doxorubicin treatment of pediatric patients with high-risk acute lymphoblastic leukemia: associations with long-term echocardiographic outcomes. J. Clin. Oncol. 30(10), 1042-1049 (2012).

- This randomized trial (DFCI 95-01) in children with high-risk acute lymphoblastic leukemia showed that increases in cTnT and ProBNP levels after treatment were greater in patients who did not receive dexrazoxane. Increases in these biomarkers were associated with abnormal left ventricular echocardiographical parameters 4 years later.

12. Mascarenhas L, Malogolowkin M, Armenian SH et al. A Phase I study of oxaliplatin and doxorubicin in pediatric patients with relapsed or refractory extracranial non-hematopoietic solid tumors. Pediatr. Blood Cancer 60(7), 1103-1107 (2013).

13. Schloemer NJ, Brickler M, Hoffmann R et al. Administration of dexrazoxane improves cardiac indices in children and young adults with acute myeloid leukemia (AML) while maintaining survival outcomes. J. Pediatr. Hematol. Oncol. 39(5), e254-e258 (2017).

14. Schwartz CL, Wexler LH, Krailo MD et al. Intensified chemotherapy with dexrazoxane cardioprotection in newly diagnosed nonmetastatic osteosarcoma: a report from the Children's Oncology Group. Pediatr. Blood Cancer 63(1), 54-61 (2016).

15. Seif AE, Walker DM, Li Y et al. Dexrazoxane exposure and risk of secondary acute myeloid leukemia in pediatric oncology patients. Pediatr. Blood Cancer 62(4), 704-709 (2015).

- This large ( $(\mathrm{n}=15: 532)$ retrospective cohort study investigated children with newly identified malignancies (excluding acute myeloid leukemia) receiving anthracyclines between 1 January 1999 and 31 March 2011 (1406 [9.1\%] received dexrazoxane). The incidence of secondary acute myeloid leukemia did not differ between dexrazoxane-exposed $(0.21 \%)$ and unexposed $(0.55 \%)$ children (unadjusted odds ratio: 0.39, 95\% CI: 0.04-0.62).

16. Tran HC, Marachelian A, Venkatramani R et al. Oxaliplatin and doxorubicin for relapsed or refractory high-risk neuroblastoma. Pediatr. Hematol. Oncol. 32(1), 26-31 (2015).

17. Vrooman LM, Neuberg DS, Stevenson KE et al. The low incidence of secondary acute myelogenous leukaemia in children and adolescents treated with dexrazoxane for acute lymphoblastic leukemia: a report from the Dana-Farber Cancer Institute ALL Consortium. Eur. J. Cancer 47(9), 1373-1379 (2011).

18. Shkalim-Zemer V, Ash S, Toledano $\mathrm{H}$ et al. Highly effective reduced toxicity dose-intensive pilot protocol for non-metastatic limb osteogenic sarcoma (SCOS 89). Cancer Chemother. Pharmacol. 76(5), 909-916 (2015).

19. Abdel-Qadir H, Ong G, Fazelzad R et al. Interventions for preventing cardiomyopathy due to anthracyclines: a Bayesian network meta-analysis. Ann. Oncol. 28(3), 628-633 (2017).

20. Kalam K, Marwick TH. Role of cardioprotective therapy for prevention of cardiotoxicity with chemotherapy: a systematic review and meta-analysis. Eur. J. Cancer 49(13), 2900-2909 (2013).

21. Shaikh F, Dupuis LL, Alexander S et al. Cardioprotection and second malignant neoplasms associated with dexrazoxane in children receiving anthracycline chemotherapy: a systematic review and meta-analysis. J. Natl Cancer Inst. 108(4), djv357 (2016).

- This recent meta-analysis (17 studies; 4639 patients) concluded that dexrazoxane was associated with reduced subclinical (asymptomatic) and clinical cardiotoxicity and did not affect overall survival or the incidence of second primary malignancies.

22. van Dalen EC, Caron HN, Dickinson $\mathrm{HO}$ et al. Cardioprotective interventions for cancer patients receiving anthracyclines. Cochrane Database Syst. Rev. 6, CD003917 (2011).

-. This Cochrane Group review included ten randomized controlled trials where cancer patients $(n=1: 619)$ received dexrazoxane for cardioprotection. The meta-analysis showed a statistically significant benefit in favor of dexrazoxane for the occurrence of heart failure (relative risk: $0.29,95 \% \mathrm{CI}$ : 0.20-0.41) and no evidence for a difference in response rate, survival or occurrence of secondary primary malignancies between the dexrazoxane and control groups.

23. Asselin BL, Devidas M, Wang C et al. Effectiveness of high-dose methotrexate in T-cell lymphoblastic leukemia and advanced-stage lymphoblastic lymphoma: a randomized study by the Children's Oncology Group (POG 9404). Blood 118(4), 874-883 (2011). 
24. Tebbi CK, London WB, Friedman D et al. Dexrazoxane-associated risk for acute myeloid leukemia/myelodysplastic syndrome and other secondary malignancies in pediatric Hodgkin's disease. J. Clin. Oncol. 25(5), 493-500 (2007).

25. Lipshultz SE, Lipsitz SR, Orav EJ. Dexrazoxane-associated risk for secondary malignancies in pediatric Hodgkin’s disease: a claim without compelling evidence. J. Clin. Oncol. 25(21), 3179 (2007).

26. Hellmann K. Dexrazoxane-associated risk for secondary malignancies in pediatric Hodgkin's disease: a claim without evidence. J. Clin. Oncol. 25(29), 4689-4690 (2007).

27. Tebbi CK, Mendenhall NP, London WB et al. Response-dependent and reduced treatment in lower risk Hodgkin lymphoma in children and adolescents: results of P9426: a report from the Children's Oncology Group. Pediatr. Blood Cancer 59(7), 1259-1265 (2012).

28. Cvetkovic RS, Scott LJ. Dexrazoxane. A review of its use for cardioprotection during anthracycline chemotherapy. Drugs 65(7), 1005-1024 (2005).

29. Jardim DL, Rodrigues CA, Novis YA et al. Oxaliplatin-related thrombocytopenia. Ann. Oncol. 23(8), 1937-1942 (2012).

30. Swain SM, Whaley FS, Gerber MC et al. Cardioprotection with dexrazoxane for doxorubicin-containing therapy in advanced breast cancer. J. Clin. Oncol. 15(4), 1318-1332 (1997).

31. Lipshultz SE, Scully RE, Lipsitz SR et al. Assessment of dexrazoxane as a cardioprotectant in doxorubicin-treated children with high-risk acute lymphoblastic leukaemia: long-term follow-up of a prospective: randomised: multicentre trial. Lancet Oncol. 11(10), 950-961 (2010).

32. Lipshultz SE, Franco VI, Sallan SE et al. Dexrazoxane for reducing anthracycline-related cardiotoxicity in children with cancer: an update of the evidence. Prog. Pediatr. Cardiol. 36(1-2), 39-49 (2014).

33. Friedman DL, Meadows AT. Late effects of childhood cancer therapy. Pediatr. Clin. North Am. 49(5), 1083-1106 (2002).

34. Henderson TO, Friedman DL, Meadows AT. Childhood cancer survivors: transition to adult-focused risk-based care. Pediatrics 126(1), 129-136 (2010).

35. Siegel RL, Miller KD, Jemal A. Cancer statistics: 2015. CA Cancer J. Clin. 65(1), 5-29 (2015).

36. Wisnivesky JP, Smith CB, Packer S et al. Survival and risk of adverse events in older patients receiving postoperative adjuvant chemotherapy for resected stages II-IIIA lung cancer: observational cohort study. BMJ 343, d4013 (2011).

37. Franco VI, Lipshultz SE. Cardiac complications in childhood cancer survivors treated with anthracyclines. Cardiol. Young 25(Suppl. 2), $107-116$ (2015).

38. Mertens AC, Liu Q, Neglia JP et al. Cause-specific late mortality among 5-year survivors of childhood cancer: the Childhood Cancer Survivor Study. J. Natl Cancer Inst. 100(19), 1368-1379 (2008).

39. Mellman I, Coukos G, Dranoff G. Cancer immunotherapy comes of age. Nature 480(7378), 480-489 (2011).

40. Vanneman M, Dranoff G. Combining immunotherapy and targeted therapies in cancer treatment. Nat. Rev. Cancer 12(4), 237-251 (2012).

41. Leger $\mathrm{K}$, Slone $\mathrm{T}$, Lemler $\mathrm{M}$ et al. Subclinical cardiotoxicity in childhood cancer survivors exposed to very low dose anthracycline therapy. Pediatr. Blood Cancer 62(1), 123-127 (2015).

42. Vejpongsa P, Yeh ETH. Prevention of anthracycline-induced cardiotoxicity: challenges and opportunities. J. Am. Coll. Cardiol. 64(9), 938-945 (2014).

43. Bielack SS, Erttmann R, Kempf-Bielack B et al. Impact of scheduling on toxicity and clinical efficacy of doxorubicin: what do we know in the mid-nineties? Eur. J. Cancer 32A(10), 1652-1660 (1996).

44. Duggan ST, Keating GM. Pegylated liposomal doxorubicin: a review of its use in metastatic breast cancer: ovarian cancer: multiple myeloma and AIDS-related Kaposi's sarcoma. Drugs 71(18), 2531-2558 (2011).

45. Kalay N, Basar E, Ozdogru I et al. Protective effects of carvedilol against anthracycline-induced cardiomyopathy. J. Am. Coll. Cardiol. 48(11), 2258-2262 (2006).

46. Lipshultz SE, Lipsitz SR, Sallan SE et al. Long-term enalapril therapy for left ventricular dysfunction in doxorubicin-treated survivors of childhood cancer. J. Clin. Oncol. 20(23), 4517-4522 (2002).

47. Hutchins KK, Siddeek H, Franco VI et al. Prevention of cardiotoxicity among survivors of childhood cancer. Br. J. Clin. Pharmacol. 83(3), 455-465 (2017).

48. Wu V. Dexrazoxane: a cardioprotectant for pediatric cancer patients receiving anthracyclines. J. Pediatr. Oncol. Nurs. 32(3), 178-184 (2015).

49. Feijen EA, Leisenring WM, Stratton KL et al. Equivalence ratio for daunorubicin to doxorubicin in relation to late heart failure in survivors of childhood cancer. J. Clin. Oncol. 33(32), 3774-3780 (2015).

50. Curigliano G, Cardinale D, Suter T et al. Cardiovascular toxicity induced by chemotherapy: targeted agents and radiotherapy: ESMO Clinical Practice Guidelines. Ann. Oncol. 23(Suppl. 7), vii155-vii166 (2012).

51. Hensley ML, Hagerty KL, Kewalramani T et al. American Society of Clinical Oncology 2008 clinical practice guideline update: use of chemotherapy and radiation therapy protectants. J. Clin. Oncol. 27(1), 127-145 (2009). 